\title{
AKTIVITAS ANTIBAKTERI FRAKSI-FRAKSI DAUN Colocacia esculenta L. TERHADAP Salmonella thypi Dan Staphylococcus aureus SECARA BIOAUTOGRAPHY-TLC
}

\author{
Muzakkir Baits, Herwin, Ririn \\ Fakultas Farmasi Universitas Muslim Indonesia Makassar \\ Email : muzakkirbaits@gmail.com
}

\begin{abstract}
Antibacterial activity test has been done on Colocacia esculenta $L$ leaves fractions. The aim of the research was to determine the antibacterial activity of Colocacia esculenta $L$ leaves fractions delivered from Pare-Pare District of South Sulawesi on Salmonella thypii and Staphyllococcus aureus by means of vacuum liquid chromatography and Bioautographic-TLC. Results of fractionations of the ethanol extract by the former method using eluent of $100 \mathrm{~mL} n$-hexane, $n$ hexane:ethyl acetate (10:1; 1:1), $100 \mathrm{~mL}$ ethyl acetate, ethyl acetate:methanol (10:1; $1: 1)$ and $100 \mathrm{~mL}$ methanol were obtained 7 fractions. Bioautographic-TLC assay then carried out on the obtained fractions they were fraction 3,4,5,6 and 7 respectively and obtained $R f$ value 0.80 was possessed antibacterial activity on both tested bacteria.
\end{abstract}

Keywords : Leaves fraction of Colocacia esculenta L, Bioautography-TLC, Antibacterial.

\section{PENDAHULUAN}

Penemuan berbagai senyawa obat baru dari bahan alam semakin memperjelas peran penting metabolit sekunder tumbuhan sebagai sumber bahan baku obat. ${ }^{1}$

Kandungan metabolit sekunder ini telah terbukti bekerja sebagai derivat antikanker, antibakteri dan antioksidan alami antara lain golongan alkaloid, tanin, golongan polifenol dan turunannya yang pemanfaatannya sebagai obat alami diyakini mempunyai efek samping yang relatif kecil dibandingkan obat modern. Maka dari itu senyawa metabolit sekunder ini dalam pemanfaatannya sangat diperlukan pengujian aktivitas untuk mengetahui khasiat senyawa alami sebagai obat antibakteri. Salah satu tumbuhan yang sangat kurang termanfaatkan secara ilmiah saat ini adalah daun Colocacia esculenta L. dari Pare-Pare Sulawesi Selatan yang dimanfaatkan sebagai obat radang, kulit bernanah, berak darah, bisul, dan luka bakardengan kandungan kimia saponin, terpen, tanin, flavonoid, 
Aktivitas Antibakteri Fraksi-Fraksi Daun Colocacia esculenta L. Terhadap Salmonella thypi Dan Staphylococcus aureus Secara Bioautography-TLC

flobatanin, antraquinon, glikosida jantung, dan alkaloid. $^{2}$ Senyawa Tersebut sangat potensial pemanfaatannya Sebagai antibakteri alami untuk penanggulangan infeksi bakteri patogennamun secara ilmiah pemanfaatan daun Colocacia esculenta L. sebagai obat antibakteri alami belum terealisasikan. ${ }^{4}$

Penelitian pendahuluan yang telah dilakukan adalah skrining, penelusuran golongan komponen kimia dan aktivitas antibakteri berdasarkan diameter zona hambatan pada konsentrasi ekstrak etanol dari daun Colocacia esculenta L. terhadap bakteri patogen Salmonella thypi sangat potensial digunakan sebagai antibakteri alami. ${ }^{3}$

Dengan adanya aktivitas dan kandungan kimia ekstrak etanol daun Colocacia esculenta L. yang potensial sebagai senyawa bioaktif alami tersebut, perlu dilakukan penelusuran komponen kimia aktif dengan cara difraksinasi secara kromatografi cair vakum sehingga dapan mengetahui fraksi aktif sebagai antibakteri dengan cara Bioautography-TLC. Berdasarkan hal tersebut, maka dilakukan penelitian aktivitas fraksi-fraksi dari ekstrak etanol daun Colocacia esculenta L. sebagai antibakteri alami dalam penaggulangan infeksi bakteri patogen yang diperoleh dari pasien sehingga penggunaannya dalam masyarakat lebih dapat dipertanggungjawabkan.

\section{METODE PENELITIAN}

\section{Tempat dan Waktu Penelitian}

Penelitian dilaksanakan di Laboratorium Mikrobiologi, Fitokimia, Fakultas Farmasi Universitas Muslim Indonesia Makassar 2016.

\section{Bahan dan Alat Penelitian}

Bahan utama dalam penelitian ini, daun Colocacia esculenta dari Pare-Pare Sulawesi Selatan, aquadest, biakan murni bakteri pathogen Salmonella thypi, Staphylococcus aureus, ATTC 2016), DMSO (Dimetil sulfoksida) (E.Merck), kloramfenikol (PT. Alpharma), kloroform p.a (E.Merck), n-heksan p.a (E.Merk), etil asetat p.a (E.Merk), larutan $\mathrm{NaCl}$ fisiologis $0,9 \%$, medium GNA (Glukosa Nutrien Agar), medium NA (Nutrien Agar), medium NB (Nutrien Broth), metanol p.a, reagen semprot (aluminium triklorida, Dragendorff, Liebermann-Buchard, asam sulfat $10 \%$, uap amonia, $\mathrm{FeCl} 3$ ), H2SO4 p.a.

Alat yang digunakan adalah timbangan analitik, rotavapor, sentrifuge, autoklaf, oven, laminar air flow (LAF), inkubator, bejana maserasi, botol pengencer, cawan petri, chamber, corong, corong pisah 
Aktivitas Antibakteri Fraksi-Fraksi Daun Colocacia esculenta L. Terhadap Salmonella thypi Dan Staphylococcus aureus Secara Bioautography-TLC

$500 \mathrm{ml}$, labu ukur $50 \mathrm{ml}$, lampu spiritus, penangas air, timbangan kasar, cawan porselen.

\section{Presedur Penelitian}

Pengambilan Dan Ekstraksi Sampel

Daun Colocacia esculenta Secara Maserasi

Daun Colocacia esculenta L. yang diperoleh dari Pare-Pare Sulawesi Selatan terlebih dahulu disortasi dengan tujuan untuk memisahkan kotoran-kotoran yang melekat pada sampel sehingga sampel yang dibutuhkan sesuai dengan yang diperlukan. Proses pemisahan kotoran dilakukan dengan air mengalir hingga bersih dan diangin-anginkan diudara bebas dan tidak terkena matahari secara langsung. Sampel yang diperoleh dideterminasi dan standarisasi simplisia untuk dilakukan ekstraksi secara maserasi menggunakan etanol 96\%. Sampel daun Colocacia esculenta diekstraksi selama 5 hari dengan dilakukan pengadulan setiap 24 jam. Hasil ekstraksi dilakukan penguapan menggunakan rotavapor sehingga diperoleh ekstrak etanol daun Colocacia esculenta.

Fraksinasi Senyawa Bioaktif

Ekstrak Etanol Daun Colocacia esculenta Secara Kromatografi Cair Vakum
Ekstrak etanol daun Colocacia esculenta 5 gram dilakukan fraksinasi pada fase diam silica gel G 60 F254 dan fase gerak menggunakan $n$ heksan $100 \mathrm{ml}$, n-heksan : etil asetat $(10: 1 ; 1: 1) 100 \mathrm{ml}$, etil asetata $100 \mathrm{ml}$, etil asetat : metanol $(10: 1 ; 1: 1) 100 \mathrm{ml}$ dan metanol $100 \mathrm{ml}$. Hasil fraksinasi dilakukan pengujian aktivitas antibakteri terhadap bakteri Salmonella thypi dan Staphylococcus aureus secara Bioautography TLC.

\section{Pengujian Aktivitas Antibakteri} Fraksi Salmonella thypi dan Staphylococcus aureus Secara Bioautography-TLC

Fraksi daun

Colocacia esculenta $\mathrm{L}$. hasil fraksinasi yang telah ditotolkan pada lempeng kromatografi lapis tipis (KLT) dengan ukuran $7,5 \times 1$ $\mathrm{cm}$, lalu dielusi dalam chamber yang berisi eluen (fase gerak). Setelah terelusi pada lempeng dibiarkan kering, lalu dimasukkan ke dalam cawan petri, dengan cara penempelan antara permukaan medium nutrien agar yang telah diinokulasi bakteri patogen Salmonella typhi dan Staphylococcus aureus dengan permukaan fraksi yang telah ditotol, kemudian dibiarkan berdifusi selama 60 menit lalu diangkat. Diinkubasi pada suhu $37^{\circ} \mathrm{C}$ selama $1 \times 24$ jam. Diamati zona penghambatan terhadap 
Aktivitas Antibakteri Fraksi-Fraksi Daun Colocacia esculenta L. Terhadap Salmonella thypi Dan Staphylococcus aureus Secara Bioautography-TLC

bakteri patogen pada medium dan metode kromatografi cair vakum diukur Rf senyawa aktif pada lempeng menggunakan eluen n-heksan $100 \mathrm{ml}$, KLT.

\section{HASIL PENELITIAN}

Ekstrak etanol daun Colocacia n-heksan : etil asetat $(10: 1,1: 1)$ etil asetat $100 \mathrm{ml}$, etil asetat : metanol (10:1, 1:1), metanol $100 \mathrm{ml}$. Hasil esculenta L. ditimbang sebanyak 5 fraksinasi terlihat pada tabel 1 . gram kemudian difraksinasi dengan

Tabel 1. Hasil Fraksinasi Ekstrak etanol daun Colocacia esculenta L. Dengan Metode Kromatografi Cair Vakum.

\begin{tabular}{ccccc}
\hline \multirow{2}{*}{ Fraksi } & \multirow{2}{*}{ Bercak } & Rf & \multicolumn{2}{c}{ Penampak Bercak } \\
\cline { 4 - 5 } & & & UV 254 $\mathbf{n m}$ & UV 366 $\mathbf{~ n m}$ \\
\hline 1 & - & - & - & - \\
\hline 3 & 1 & 0.98 & Biru & Berpendar \\
\hline 3 & 1 & 0.94 & Kuning & Orange \\
\hline \multirow{2}{*}{4} & 1 & 0.93 & Coklat & Orange \\
& 2 & 0.89 & Kuning & Orange \\
\hline & 1 & 0.98 & Orange & Coklat \\
\multirow{2}{*}{5} & 2 & 0.89 & Coklat & Kuning \\
& 3 & 0.46 & Orange & Ungu \\
& 4 & 0.23 & Orange & Kuning \\
\hline & 1 & 0.98 & Orange & Koklat \\
& 2 & 0.89 & Orange & Kuning \\
& 3 & 0.46 & Orange & Coklat \\
\hline 7 & 4 & 0.23 & Orange & Kuning \\
\hline
\end{tabular}

Pengujian Aktivitas Antibakteri

Fraksi Daun Colocacia esculenta L. Terhadap Bakteri Salmonella thypi dan Staphylococcus aureus Dengan Metode KLT-Bioautografi.

Fraksi Daun Colocacia esculenta L. yang diperoleh dari hasil fraksinasi dengan metode kromatografi cair vakum, dilakukan pengujian aktivitas antibakteri secara Bioautografi menggunakan eluen $n$ heksan : etil asetat (10:1) diperoleh nilai $\mathrm{Rf} 0.70$ Memberikan aktivitas terhadap Salmonella thypi, terlihat pada tabel 2. 
Uji daya hambat ekstrak etil asetat daun binahong (Anredera coliforlia (Ten.) Steenis) terhadap pertumbuhan bakteri Staphylococcus aureus dan Escherichia coli.

Tabel 2. Hasil pengujian aktivitas antibakteri Senyawa Murni daun Colocacia esculenta L. secara KLT-Bioautografi.

\begin{tabular}{cllll}
\hline \multirow{2}{*}{ Rf } & \multicolumn{2}{c}{ Penampak bercak } & & \multirow{2}{*}{ Bakteri Uji } \\
\cline { 2 - 3 } & UV 254 nm & UV $366 \mathbf{~ n m}$ & \\
\cline { 1 - 2 } 0.70 & Kuning & Ungu & Salmonella thypi \\
& Staphylococcus aureus \\
\hline
\end{tabular}

PEMBAHASAN

Ekstraksi daun Colocacia esculenta disari dengan metode maserasi karena proses penyarian berlangsung secara dingin sehingga senyawa yang dikhawatirkan rusak oleh pemanasan tidak terjadi, yaitu hanya dengan merendam sampel dalam cairan penyari yang sesuai. daun Colocacia esculenta dicuci sampai bersih dengan air untuk menghilangkan kotoran-kotoran lain yang melekat pada permukaan daun Colocacia esculenta. Daun Colocacia esculenta diekstraksi dengan menggunakan cairan penyari etanol $96 \%$. Penggunaan cairan penyari etanol pada penelitian ini karena bersifat semipolar sehingga dapat menyari komponen kimia yang bersifat polar maupun non polar, sehingga diharapkan relatif semua komponen kimia dalam sampel akan terekstraksi. Pada saat perendaman daun Colocacia esculenta dalam etanol, konsentrasi di luar sel lebih tinggi daripada di dalam sel sehingga isi sel termasuk zat aktifnya akan keluar dan terlarut dalam etanol. Proses penyarian dilakukan $3 \times 24$ jam dengan pergantian cairan penyari yang baru pada sampel yang sama diharapkan zat aktif yang dikehendaki dapat diperoleh semuanya. Pengujian antibakteri memberikan aktivitas terhadap bakteri Gram negatif dan Gram positif, hal ini terjadi karena adanya kesamaan struktur dan komponen penyusun dinding sel dari keduanya, yaitu dinding sel bakteri gram negatif lebih kompleks menimbulkan rintangan yang besar bagi bahan antimikroba untuk dapat menembusnya

Dinding sel bakteri gram negatif mempunyai dua lapisan dinding sel yaitu lapisan luar yang tersusun atas lipopolisakarida dan protein serta lapisan dalam tersusun atas lapisan peptidoglikan satu yang lebih tipis dari pada lapisan peptidoglikan pada bakteri gram positif yang hanya tersusun atas satu lapis saja yaitu lapisan peptidoglukan yang relative tebal. Perbedaan ini sangat mempengaruhi Kemampuannya dalam 
Uji daya hambat ekstrak etil asetat daun binahong (Anredera coliforlia (Ten.) Steenis) terhadap pertumbuhan bakteri Staphylococcus aureus dan Escherichia coli.

melawan agen antimikroba yaitu dinding sel bakteri gram negatif yang kompleks menimbulkan rintangan yang besar bagi bahan antimikroba untuk dapat menembusnya. Colocassia esculenta merupakan tamnaman yang luas tumbuh di Indonesia. Daun talas telah digunakan oleh masyarakat sebagai sayuran, pembungkus makanan dan makanan ternak. Dalam meningkatkan penggunaan daun talas sebagai bahan obat maka dilakukan proses ekstraksi untuk mengeluarkan senyawasenyawa yang berpotensi sebagai bahan terapeutik. Ekstraksi 2,650 mg daun dengan menggunakan metode maserasi menghasilkan 30 gram ekstrak kental ekstrak etanol daun Colocacia esculenta L. difraksinasi dengan metode kromatografi cair vakum menggunakan eluen $n$-heksan $100 \mathrm{ml}$, n-heksan : etil asetat (10:1, 1:1) etil asetat $100 \mathrm{ml}$, etil asetat : metanol $(10: 1,1: 1)$, metanol $100 \mathrm{ml}$ diperoleh 7 fraksi yaitu Fraksi 1, Fraksi 2, Fraksi 3, Fraksi 4, Fraksi 5, Fraksi 6 dan Fraksi 7. Berdasarkan hasil pengujian aktivitas antibakteri yaitu fraksi 3, 4, 5, 6 dan 7 secara Bioautography-TLC diperoleh nilai Rf 0.80 memberikan aktivitas antibakteri terhadap bakteri Salmonella thypi dan
Staphylococcus aureus merupakan golongan komponen kimia flavonoid menggunakan pereaksi $\mathrm{FeCl} 3$.

\section{KESIMPULAN}

Fraksinasi ekstrak etanol daun Colocacia esculenta $L$. secara kromatografi cair vakum diperoleh 7 fraksi. Hasil pengujian aktivitas antibakteri Fraksi Daun Colocasia esculenta L. yaitu fraksi 3, 4, 5, 6 dan 7 secara bioautography-TLC diperoleh nilai $\mathrm{Rf} 0.80$ aktif terhadap bakteri Salmonella thypi dan Staphylococcus aureus merupakan golongan komponen kimia flavonoid menggunakan pereaksi FeCl3.

\section{DAFTAR PUSTAKA}

1. Dalimatra S. AtlasTumbuhan Obat Indonesia.Jilid 4. Jakarta : Puspa Swara Indonesia, 2006.

2. Bhagyashree RP. Antihepatotoxic Activity Of Colocasia esculenta Leaf Juice. International Journal of Advanced Biotechnology and Research 2011;2(2): 296-304.

3. Herwin. Skrining dan Penelusuran Golongan Komponen Kimia Aktif Ekstrak Etanol Daun Colocacia esculenta L. Terhadap Beberapa Mikroba Uji Secara KLTBioautografi. Makassar : Fakultas Farmasi UMI, 2013.

4. Sampurno. Kebijakan Pengembangan Obat Bahan Alam Indonesia. Seminar Nasional Tumbuhan Obat Indonesia XXIII. Jakarta : Universitas Pancasila, 2003. 